Nepal Journal of Science and Technology Vol. 15, No.1 (2014) 129-132

\title{
Detection of Pyuria versus Bacteriuria in Suspected Patients of Urinary Tract Infection
}

\author{
Anjila Dongol ${ }^{1}$, Durga Man Joshi ${ }^{2}$ and Avishekh Gautam ${ }^{1}$ \\ ${ }^{1}$ St. Xavier's College, Kathmandu, Nepal \\ ${ }^{2}$ Kathmandu Hospital, Kathmandu, Nepal \\ e-mail: anjiladongol0@gmail.com
}

\begin{abstract}
Urinary tract infection (UTI) is one of the most important causes of mortality and morbidity in the world affecting all age groups across the life span. The aim of this study is to determine incidence of bacteriuria and its relation with pyuria in suspected urinary tract infection. This crosssectional-descriptive-analytical study was conducted in microbiology section of Kathmandu Hospital, Tripureshwor from May to August 2011. During this period, 412 midstream urine samples collected were investigated by microscopic examination of centrifuged urine sediment and conventional semi-quantitative culture technique. Out of $412 \mathrm{MSU}$ samples, 120 (29.13\%) were culture positive. The remaining $22(18.33 \%)$ samples showed low count significant bacteriuria (i.e $10^{4}-10^{5} \mathrm{CFU} / \mathrm{ml}$ ) and $98(81.67 \%)$ showed significant bacteriuria (i.e. $\geq 10^{5} \mathrm{CFU} / \mathrm{ml}$ ). Among 88 urine samples with significant pyuria, only $74(84.09 \%)$ showed culture positive. Out of 324 urine samples without significant pyuria, $46(14.19 \%)$ urine samples showed culture positive result. Significant pyuria was found to have sensitivity of $61.67 \%$, specificity of $95.21 \%$ and the test has $84.09 \%$ positive predictive value in detecting bacteriuria. Pyuria and bacteriuria may not always correlate in the suspected case of UTI.
\end{abstract}

Key words: pyuria, bacteriuria, urinary tract infection, culture

\section{Introduction}

Urinary tract infection is the most important cause of mortality and morbidity in the world affecting all age groups across the life span (Basnet et al. 2009). It is estimated that 150 million cases of UTI occur on a global basis per year resulting in more than 4 billion pounds ( 6 billion dollars) in direct health care expenditure (Kucheria et al. 2005). According to the annual report published by Department of Health Services (2059/60), morbidity of UTI in Nepal is $1,25,058$. Nepalese patients attending general hospitals ranged from $23.1 \%$ to $37.4 \%$ (Rai et al. 2008).

Urinary tract infections are a spectrum of diseases caused by microbial invasion of the genitourinary tract that extends from the renal cortex of the kidney to the urethral meatus (Mahon et al. 2007). The presence of pyuria and bacteriuria are two most important indicators of urinary tract infections (Douri 2008).
Bacteriuria is defined as the presence of $>10^{5}$ colonies of a single pathogen per milliliter of urine (Celen et al. 2011). A more current definition is the presence of as few as $10^{3} \mathrm{CFUs} / \mathrm{ml}$ in symptomatic patients or when a specimen is obtained by sterile catherization (Baum and Heintz 2008). Pyuria is defined as the presence of white blood cells (WBCs) in a person's urine (Adegoke et al. 2011).

Bacteriuria without pyuria may occur in cases of asymptomatic patient with diabetes, enteric fever or bacterial endocarditis or during pregnancy (Kattel et al. 2009). Pyuria with a sterile routine culture may be found with renal tuberculosis, gonococcal urethritis, C. trachomatis infections and leptospirosis (Cheesbrough 2006). Pyuria can occur in the absence of apparent bacterial infection, particularly in patients who have already taken antimicrobials, calculus 
disease, stricture, neoplasm and glomerulonephropathy. In female patients, pyuria can occur due to leucorrhea, fever, pregnancy and administration of adrenocortical steroids without infection (Santos et al. 2007). This study was conducted to determine the incidence of bacteriuria and relationship between pyuria and bacteriuria.

\section{Methodology}

A crossectional-descriptive-analytical study was carried out at bacteriology laboratory of Kathmandu hospital, Tripureshwor during May 2011 to August 2011 of suspected UTI patients (both outpatient and inpatient) visiting Kathmandu Hospital. Four hundred and twelve clean catch mid-stream urine samples were collected from patients for urine routine test and culture. The samples were collected and processed by standard bacteriology method. Ten $\mathrm{ml}$ of urine sample was taken in a clean sterile centrifuge tube and centrifuged at $3000 \mathrm{rpm}$ for $10 \mathrm{~min}$. The supernatant was discarded. The sediment was then examined for presence of the pus cells by wet mount preparation. The pus cells $>5 / \mathrm{HPF}$ were considered as significant. The samples were subjected to standard bacterial culture of Blood and MacConkey agar plates according to the standard laboratory methods (Procedures/ Guidelines for the Microbiology Laboratory 2010). The plates were observed for bacterial growth after 18 hours incubation at $37^{\circ} \mathrm{C}$ aerobically. The bacteria were identified by colony characters, Gram's reaction and biochemical properties. Bacterial colonies more than $10^{5}$ colony forming units per $\mathrm{ml}$ of urine were considered as significant. Chi-square test was done wherever applicable with a $\mathrm{P}$ value $<0.05$ regarded as significant.

\section{Results and Discussion}

Out of 412 urine samples, 221 were from females and 191 were from males. Of the total samples, 22 (5.34\%) samples showed low count significant bacteriuria and $98(23.79 \%)$ showed significant bacteriuria (Fig. 1).

Among 412 urine samples, 88(21.36\%) showed significant pyuria, $69(16.75 \%)$ showed insignificant pyuria and $255(61.89 \%)$ had no pus cells.

Out of $88(100 \%)$ samples with significant pyuria, 74 $(84.09 \%)$ were culture positive, while $46(14.19 \%)$ out of $324(100 \%)$ with no significant pyuria were culture positive. The test had sensitivity, specificity, positive and negative predictive values of $61.67 \%$, $95.21 \%, 84.09 \%$ and $85.80 \%$ respectively. Pyuria and bacteriuria were correlated statistically $(\mathrm{P}<0.05)$ (Table 1).

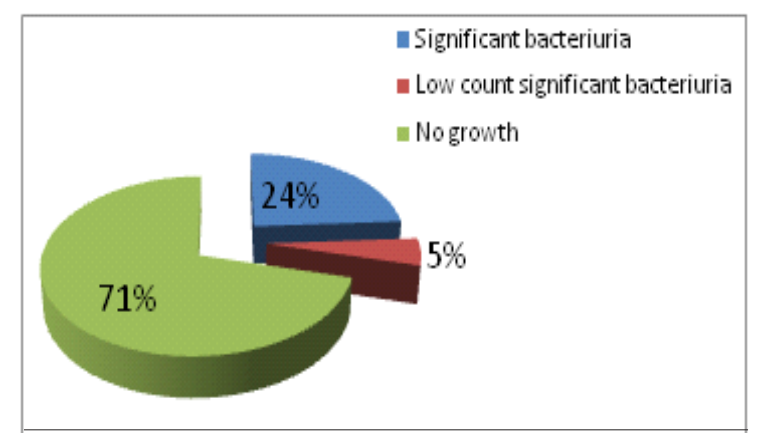

Fig. 1. Pattern of urine culture results

Table 1. Correlation of pyuria with culture result

\begin{tabular}{l|c|c|c}
\hline \multicolumn{1}{c|}{ Pyuria } & $\begin{array}{c}\text { Culture } \\
\text { positive } \\
(\%)\end{array}$ & $\begin{array}{c}\text { Culture } \\
\text { negative } \\
(\%)\end{array}$ & $\begin{array}{c}\text { Total } \\
(\%)\end{array}$ \\
\hline $\begin{array}{l}\text { Significant } \\
(>5 \mathrm{WBC} / \mathrm{HPF})\end{array}$ & $74(84.09)$ & $14(15.9)$ & $88(21.35)$ \\
$\begin{array}{l}\text { No significant } \\
\text { pyuria } \\
(\leq 5 \mathrm{WBC} / \mathrm{HPF})\end{array}$ & $46(14.19)$ & $278(85.8)$ & $324(78.64)$ \\
Total & $120(29.13)$ & $292(70.87)$ & $412(100)$ \\
\hline
\end{tabular}

As shown in Table 2, 28 samples out of 29 having 6-10 pus/HPF in microscopy were culture positive. When infections were analyzed by the organisms causing infection, 61.21 percent infection caused by Gram negative Bacilli, $66.67 \%$ by Staphylococci and single isolate of Streptococci were accompanied with significant pyuria (Table 3 ).

\section{Table 2. Pyuriaversus Bacteriuria}

\begin{tabular}{l|c|c|c}
\hline $\begin{array}{c}\text { Pus cells } \\
\text { /HPF }\end{array}$ & $\begin{array}{c}\text { No of } \\
\text { samples }\end{array}$ & $\begin{array}{c}\text { Culture } \\
\text { positive (\%) }\end{array}$ & $\begin{array}{c}\text { Culture } \\
\text { negative (\%) }\end{array}$ \\
\hline 0 & 255 & $31(12.16)$ & $224(87.84)$ \\
$1-5$ & 69 & $15(21.74)$ & $54(78.26)$ \\
$6-10$ & 29 & $28(96.55)$ & $1(3.45)$ \\
$11-20$ & 25 & $18(72)$ & $7(28)$ \\
$21-50$ & 21 & $19(90.48)$ & $2(9.52)$ \\
$>50$ & 13 & $9(69.23)$ & $4(30.77)$ \\
Total & 412 & $120(29.13)$ & $292(70.87)$ \\
\hline
\end{tabular}


Anjila Dongol et al./Detection of Pyuria versus

Table 3. Bacterial agents in significant and insignificantpyuria

\begin{tabular}{l|c|c|c|c}
\hline Bacterial agents & Significant pyuria (\%) & Insignificant pyuria (\%) & No pyuria (\%) & Total \\
\hline E. coli & $60(62.5)$ & $13(13.54)$ & $23(23.96)$ & 96 \\
K. pneumoniae & $4(50)$ & $1(12.5)$ & $3(37.5)$ & 8 \\
K. oxytoca & $1(25)$ & $1(25)$ & $2(50)$ & 4 \\
P. vulgaris & $1(50)$ & $0(0)$ & $1(50)$ & 2 \\
P. aeruginosa & $3(100)$ & $0(0)$ & $0(0)$ & 3 \\
C. freundii & $2(66.67)$ & $0(0)$ & $1(33.33)$ & 3 \\
S. aureus & $0(0)$ & $1(100)$ & $0(0)$ & 1 \\
S. saprophyticus & $2(100)$ & $0(0)$ & $0(0)$ & 2 \\
S. faecalis & $1(100)$ & $0(0)$ & $0(0)$ & 1 \\
\hline
\end{tabular}

This study showed the relationship between pyuria and bacteriuria from suspected patients in Kathmandu Hospital. In this study, overall 23.79\% urine samples showed significant bacteriuria. Similar results were also found by other investigators (Acharya et al. 2011, Basnet et al. 2009, Shrestha et al. 2007). The low rate of growth positivity might be due to inclusion of patients under treatment, infection due to slow growing organisms or due to those organisms that were not able to grow on the routine culture media used (Khanal 2006). About five and half (22/120) of samples showing $10^{4}-10^{5}$ $\mathrm{CFU} / \mathrm{ml}$ were considered low count significant bacteriuria because the patients were either diabetic, under antibiotic treatment, specimen were taken from catheter or suspected case of acute urethral syndrome.

In this study, $84.09 \%$ (74/88) samples with significant pyuria showed culture positive result. In a similar study conducted by Kattel et al. (2009), 53.9\% urine samples showed significant bacterial growth with significant pyuria. The correlation between pyuria and bacteriuria was found to be statistically significant $(\mathrm{P}<0.05)$. As mentioned in earlier text, bacteriuria without significant pyuriaoften occur in cases of asymptomatic patients, patients with diabetes, enteric fever or bacterial endocarditis whereas significant pyuria with sterile bacterial culture occur in patients with prior antibiotic use, renal tuberculosis, corticosteroid administration, analgesic nephropathy, renal calculi or in the presence of bacteria that are not able to grow in the media used Kattel et al. (2009).

In this study, significant pyuriawas found to have sensitivity of $61.67 \%$ and specificity of $95.21 \%$.
Similar result was found in the study done by Khattak et al. (2003). The test had $84.09 \%$ positive predictive value and $85.80 \%$ negative predictive value. The high percentage of sensitivity and low percentage of specificity had also been reported (Kattel et al. 2009).

In present study, the significant bacterial growth was found to be high (96.55\%) in samples with 6-10 pus cells per HPF which agrees the statement by Dhakal et al.(2002) that the presence of 5-10 pus cells per HPF could be a good marker of UTI."

When infections were analyzed by the organisms causing infection, $61.21 \%$ infection caused by Gram negative Bacilli, $66.67 \%$ by Staphylococci and single isolate of Streptococci were accompanied with significant pyuria. But Tambyah and Maki (2000) in catheterized patients, found infections caused by Gram negative Bacilli were mostly accompanied with pyuria than coagulase negative Staphylococci, Enterococci or yeasts.

The majority of suspected patients may not have culture positive. Although pyuria and bacteriuria may not always correlate in the suspected cases of UTI, as the number of pus cells in urine increases, the chance of getting culture positive results is also high. Pyuria having low sensitivity for bacteriuria culture positive cases and low specificity for culture negative cases cannot be used as the sole criterion for the diagnosis of UTI. Hence, urine culture remains the standard method for the diagnosis of UTI.

\section{Acknowledgements}

We are grateful to all staff of Kathmandu Hospital for their kind co-operation throughout this work. 


\section{References}

Acharya, A., R. Gautam and L. Subedee. 2011. Uropathogens and their antimicrobial susceptibility pattern in Bharatpur, Nepal. Nepal Med. Coll. J. 13(1): 30-33.

Adegoke,A.O.,O.E.Bamigbowu, M.B.O. Ayodele and C.D.Blankson. 2012. Prevalence of asymptomatic bacteriuria in prostatitis subjects attending University of Port Harcourt Teaching Hospital. Afr. J. Microbiol. Res.6(21): 4443-4448.

Anomymous. 2010. Procedures/guidelines for the microbiology laboratory. College of Physicians \& Surgeons of Saskatchewan Laboratory Quality Assurance Program.1-60 pp.

Basnet, B.B., D. Thakur, K. Acharya, N. Kamacharya, R.K. Dahal, H.C Upreti and B.P. Rijal. 2009. Multidrug resistance patterns of urinary isolates in a tertiary care hospital of Nepal. JNAMLS.10: 47-52.

Baum, N. and J. Heintz. 2008. Managing urinary tract infections in the older person. Clinical Geriatrics16(8): $1-4$.

Celen, A., A.S. Oruc, R. Karayalcin, S. Saygan, S. Unlu, B. Polat and N. Danisman. 2011. Asymptomatic bacteriuria and antibacterial susceptibility patterns in an obstetric population. ISRN Obstetrics and Gynecology 721872: 1-4.

Cheesbrough, M. 2006. District laboratory practice in tropical countries. 2nd edn, Cambridge University Press.U.K. 107-115pp.

Dhakal, B.K., B.M. Pokhrel and J. Ahnn.2002. Microscopic detection of urinary tract infection in Nepalese patients. J. Microbiol. 40: 267-273.

DHS. 2059-60. Annual report. Department of Health Services, HMG Ministry of Health.

Douri, F.E. 2008.Prevalence of silent bacteriuria in patients with diabetes mellitus.The Iraqi Postgrad. Med. J. 7: 60-64.
Kattel, H.P., S.K. Mishra, J.Acharya, A.S. Shah, B.P.Rijal and B.M.Pokharel. 2009. Relationship between pyuria and bacteriuria in suspected urinary tract infection. JNAMLS10: 19-21.

Khanal, S. 2006. A study on microbiology on urinary tract infection at Tribhuvan University Teaching Hospital.M.Sc dissertation.Tribhuban University, Kirtipur.

Khattak, A.M., I.Hussain, H. Khan and D Muhammad. 2003. Evaluating the microscopic pyuria for screening covert bacteriuria during pregnancy. Gomal Journal of Medical Sciences 1: 51-53.

Kucheria, R., P. Dasgupta, S.H. Sacks, M.S. Khan and N.S.Sheerin.2005. Urinary tract infections: new insights into a common problem. Postgrad Med J. 81: 83-86.

Mahon, C.P., D.C. Lehman and G. Manuselis. 2007. Textbook of diagnostic microbiology. An Imprint of Elsevier. 1010-1028pp.

Rai, G.K., H.C.Upreti, S.K.Rai, K.P. Shah and R.M.Shrestha. 2008. Causative agents of urinary tract infections in children and their antibiotic sensitivity pattern: a hospital based study. Nepal Med. Coll. J.10(2):86-90.

Shrestha, P., S.Malla, S.Basnyat, S. Dumre, B.Upadhaya and S. Lamichhane.2007. Antimicrobial resistance pattern of bacterial isolates causing urinary tract infection. Journal of Nepal Health Reasearch Council 5: 49-54.

Tambyah, P.A. and D.G. Maki.2000. The relationship between pyuria and infection in patients with indwelling urinary catheters. Arch. Intern. Med.160: 673-677.

www.quadrant.net/cpss/pdf/Lab_QA_Microbiology_ QA.pdf Accessed 12 Jan 2010. 